\title{
The Mediterranean as a Society of Prisoners
}

\author{
Guillaume Calafat
}

Department of History, University of Paris 1, Paris, France

Email: gcalafat@univ-paris1.fr

The society of prisoners: Anglo-French wars and incarceration in the eighteenth century. By Renaud Morieux. Oxford: Oxford University Press, 2019. Pp. viii + 421. ISBN 9780198723585.

'No one's going to be interested in a story about prisoners of war!' This is the withering comment that the director Julien Duvivier supposedly made to Charles Spaak, the scriptwriter of one of the greatest films of all times, La grande illusion (1937), which was ultimately directed by Jean Renoir. Fortunately for his readers, Renaud Morieux is well aware that stories about prisoners of war can be of interest to everyone.

In his first book, The Channel, Morieux studied the political, legal, social, and cultural construction of the Franco-British maritime border during the 'long' eighteenth century. Morieux deftly combined different levels of analysis to historicize the notion of the 'border', variously taking into account cartographic representations, toponymical debates, and the trans-border mobility of fishermen and smugglers. What emerged was a picture of a plural border that was subject to ongoing negotiations and which was defined not only as a convention but also as a lived and sensory experience. With The society of prisoners, Morieux pens a further chapter of the shared history of France and Great Britain, a history which, though marked by a long series of conflicts between the two countries over the course of the eighteenth century, involves numerous common and simultaneous phenomena that are too often overlooked due to the narrow focus of the nation-state perspective and historiographies that have remained at times too separate from one another. By focusing on war captivity in a transnational perspective, Morieux here proposes an original study that blends the history of the law of nations, of the British and French fiscal-military states and of two societies at war: incarceration, as a total institution, sheds light upon both legal and moral questions surrounding the fate reserved for 'enemies' captured in wartime, diplomatic issues linked to reciprocity and interdependence, and daily problems such as the interaction between prisoners and local populations.

(C) The Author(s), 2021. Published by Cambridge University Press. This is an Open Access article, distributed under the terms of the Creative Commons Attribution licence (http://creativecommons.org/licenses/by/4.0), which permits unrestricted re-use, distribution and reproduction, provided the original article is properly cited. 
Morieux has assembled an abundant corpus of sources from both sides of the Channel, drawing in particular on the rich archives of the British Admiralty and the French 'Marine': the majority of prisoners detained during the Franco-British wars were indeed captured at sea, or travelled by sea to the sites at which they were held. This oceanic focus underlines the importance of the detention of sailors in the struggle for naval supremacy in the eighteenth century. Though approximate, the figures relating to captives that Morieux gives for the various conflicts that took place over the period spanning from the outbreak of the War of the Spanish Succession to the end of the Napoleonic Wars show that the British held far more prisoners than the French. This effort, part of a deliberate strategy by Britain to reduce France's naval manpower, required a significant investment of administrative, bureaucratic, and financial resources to organize the detention of prisoners of war. More broadly, the maritime focus of this book allows Morieux to highlight the complex status of prisoners and captives and the way in which these varied over time and space, from Europe to the colonies and from land to the high seas.

His book offers a pragmatic history of the laws of war and the law of nations, full of contingencies and exceptions, which challenges purely normative and evolutionist accounts of the history of international law. In this way, Morieux seems to imply - but perhaps I overinterpret - that historians of the eighteenth-century law of nations should maybe get rid of the very concept of international law. Building on the work of Lauren Benton and Paul Halliday in particular, Morieux places particular emphasis on the 'multiple legalities' of European empires, and the legal heterogeneity that complicates any clear-cut distinction between war and peace as well as the notion of divide between 'public' and 'private' wars. Thanks to its analysis of capture itself and the complex itineraries of prisoners of war, which spanned vast distances from the Indian Ocean to the Caribbean, The society of prisoners provides highly insightful passages on the range of prize courts and jurisdictions, the role of private forms of naval warfare, the plurality of authorities that governed captivity, and the manifold forms that captivity could take. Indeed, one of the main strengths of this book is the way in which it conceives war captivity not in terms of 'freedom' and 'unfreedom' but rather as a spectrum of legal statuses and social hierarchies running from hostage-taking to slavery, from elite officers to black sailors and soldiers, from well-treated and well-fed prisoners to dehumanized 'barbarians' or even hostes humani generis - 'enemies of mankind' - embodied in the book's epilogue by Napoleon in Saint Helena.

Morieux's study does not look in detail at the captivity of French and British individuals in the Mediterranean region, focusing mostly on the Atlantic Ocean and that 'other Mediterranean', the Caribbean world. The prospect of Mediterranean captivity, which was in fact very prominent in the imaginaries of French and British sailors, is nonetheless evoked at times, for example through the letters of an English prisoner of war who complained that he would rather be detained in Turkey than in Brittany (p. 65). Morieux rightly points out that the boundaries between captivity and slavery were, in the Mediterranean world, fairly porous - much like, in practice, the distinction between pirates and corsairs. Without minimizing certain specificities of the 
Mediterranean region, it is possible to draw numerous analogies between war captivity as studied by Morieux and phenomena that can be observed in the Mediterranean throughout the early modern period. The economy of ransoming, the practice of hostage taking, and the captives' trade amongst a range of actors - private and public, individual and collective - were indeed decisive for the structuring of diplomatic and political relations in the Mediterranean, with peace and commercial treaties often featuring clauses relating to prisoner exchanges. Furthermore, captures at sea raised similar and complex problems for those who crossed paths with the French and British surrounding the status of passengers-women and children in particular - and the nature of the protection afforded by passports and flags to variously sized vessels. Similarly, slave-prisons, the so-called bagnios, played an important role as reciprocal spaces of detainment in the Ottoman Empire and in Mediterranean Europe: these were enclosed spaces, yet permeable ones. They were frequently open to some degree to the port and urban environments that surrounded them, and prisoners of the bagnios often interacted with local populations: the letters and supplications that they sent back and forth across the Mediterranean show that captivity was a social experience common to coastal societies to the north and the south of the Inland Sea. Similarly, detention in hulks presents a number of shared dimensions with imprisonment in galleys over the winter. Finally, the term 'renegades' reserved for traitors and rebels held in detention (largely but not exclusively Irish or Huguenots) - offers a striking reflection of the anathema often used to designate European Christian captives who converted to Islam.

Though it would, of course, be possible to offset this inventory of resemblances with a long list of differences and particularities, these analogies attest to the usefulness of thinking of the Mediterranean as a 'society of prisoners', following Morieux. In other words, it is clear that the broad spectrum of war captivity as it unfolded across its multiple legal, political, and social dimensions, offers a good lens to think through the experience of detention, forced labour, slavery, and enmity in the Mediterranean. The comparison between different 'societies of prisoners' could certainly be extended to other spaces and times, further attesting to the rich comparative potential of Morieux's work and the interest it should garner beyond specialists of Franco-British relations. ${ }^{1}$

\footnotetext{
${ }^{1}$ See, for instance, for parallel debates about Ottoman-Russian conflicts of the eighteenth and nineteenth centuries: Will Smiley, From slaves to prisoners of war: the Ottoman Empire, Russia and international law (Oxford, 2018).
}

Cite this article: Calafat G (2022). The Mediterranean as a Society of Prisoners. The Historical Journal 65, 527-529. https://doi.org/10.1017/S0018246X21000376 